\title{
FAKTOR-FAKTOR YANG MEMPENGARUHI MINAT BELI MAKANAN ORGANIK
}

\author{
Elise Mustikawati \\ UniversitasTarumanagara \\ elisemustikawati9e@gmail.com \\ Louis Utama \\ UniversitasTarumanagara \\ louisu@fe.untar.ac.id \\ Tommy SetiawanRuslim \\ UniversitasTarumanagara \\ tommyr@fe.untar.ac.id \\ HenryantoWijaya \\ UniversitasTarumanagara \\ henryantow@fe.untar.ac.id
}

\begin{abstract}
The purpose of this study is to find out whether Health Consciousness, Food Safety Concern, and Perceived Valuehas an influence toward Purchase Intention of organic food in Jakarta.Data collection method used in this study is a questionnaire with quantitative approach. The sample used in this study was 40 members of Gold Gym's in Jakarta as respondents who have bought and consumed organic food in Jakarta. The sampling technique used is non-probability sampling with a convenience sampling method.The result of this study showed that 1) health consciousness affects the purchase intention of organic food 2) food safety concern affects the purchase intention of organic food. 3) perceived value affects the purchase intention of organic food.
\end{abstract}

Keywords: Health, Food Safety, Perceived Value, Purchase Intention

\begin{abstract}
ABSTRAK
Penelitian ini bertujuan untuk mengetahui apakah Tingkat Kesadaran Kesehatan, Perhatian terhadap Keamanan Pangan, dan Persepsi Nilai memiliki pengaruh terhadap Minat Beli makanan organik di Jakarta. Metode pengumpulan data yang digunakan dalam penelitian ini adalah kuesioner dengan pendekatan kuantitatif. Sampel yang digunakan dalam penelitian ini adalah 40 responden yaitu anggota Gold's Gym di Mal Ciputra Jakarta yang pernah membeli dan mengkonsumsi makanan organik di Jakarta. Teknik pengumpulan sampel yang digunakan non-probability sampling dengan metode convenience sampling. Hasil dalam penelitian ini menunjukkan :1) tingkat kesadaran kesehatan berpengaruh terhadap minat beli makanan organik. 2) perhatian terhadap keamanan pangan berpengaruh terhadap minat beli makanan organic.3) persepsi nilai berpengaruh terhadap minat beli makanan organic.
\end{abstract}

Kata kunci: Kesehatan, Keamanan Pangan, Persepsi Nilai, Minat Beli 


\section{PENDAHULUAN}

Banyak konsumen percaya bahwa makanan yang ditanam secara organik lebih aman dan bisa memberikan manfaat kesehatan yang lebih besar daripada makanan konvensional dan bisa memberikan sikap positif mereka terhadap makanan organik (Beharrel \& MacFie, 1991). Ini membuat permintaan akan makanan organik meningkat sehingga minat beli pada pasar organik juga semakin besar. Peningkatan permintaan makanan organik juga didukung dengan munculnya paradigma soal makanan yang kini telah berubah, tidak sekedar enak, mengenyangkan dan bergizi, tapi juga harus menyehatkan (Waskito, Ananto, \& Reza, 2014). Pandangan ini mendorong penyedia produk organik berlomba-lomba membuat makanan yang tidak hanya enak namun juga menyehatkan. Untuk itu, penyedia produk organik perlu mengidentifikasi faktor-faktor yang mampu meningkatkan tingkat minat beli makanan organik. Salah satu faktor seseorang mau memiliki minat beli terhadap makanan organik adalah memiliki tingkat kesadaran kesehatan yang tinggi (Asif, Xuhui, Nasiri, \& Ayyub, 2018). Masalah kesehatan muncul sebagai alasan utama untuk membeli dan mengkonsumsi makanan organik. Dengan ini, konsumen akan memiliki motivasi untuk mengkonsuriwy \& Mecking, 2012). Sehingga akan membuat konsumen memilih makanan secara bijaksana dan yang tepat untuk kondisi kesehatan mereka (Salleh, Ali, Harun, Jalil, \& Shaharudin, 2010). Hal ini juga membuat konsumen akan fokus pada aspek kesehatan dalam pilihan makanan dan sadar akan hubungan antara nutrisi dan kesehatan (Annunziata \& Pascale, 2009). Contohnya dalam membuat keputusan untuk membeli makanan organik, konsumen percaya akan manfaat kesehatannya dibandingkan dengan makanan konvensional (Shepherd, Magnusson, \& Sjödén, 2005). Selain itu, konsumen juga mulai kritis terhadap kandungan atau keamanan makanan yang mereka konsumsi. Khususnya perilaku konsumen yang mengutamakan kebersihan pada makanan (Głąbska, Skolmowska, \& Guzek, 2020). Karena pandemi Covid-19, perilaku konsumen berubah ke arah yang lebih sehat dan berkelanjutan serta konsumsi terhadap produk lokal meningkat karena adanya masalah keamanan pangan (Qi, Yu, \& Ploeger, 2020). Alasan konsumen mau membeli makanan organik adalah karena makanan organik diproses tanpa menggunakan pestisida dan materi terkait pertanian lainnya yang dapat membahayakan kesehatan tubuh (Canavari \& Olson, 2007). Konsumen 
percaya bahwa makanan organik dapat dikonsumsi tanpa perasaan khawatir terhadap keamanan makanan, sehingga konsumen akan lebih yakin untuk mengkonsumsinya (Suh, Eves, \& Lumbers, 2012). Kebiasaan itu muncul akibat adanya revolusi lifestyle global yang menyadari akan beberapa kekurangan keamanan yang ada dalam makanan konvensional (Shaharudin, Pani, Mansor, \& Elias, 2010). Yang kemudian akan mempengaruhi kerelaan konsumen untuk membayar makanan organik, sehingga dapat meningkatkan minat beli mereka (Krystallis, Fotopoulos, \& Zotos, 2006). Konsumen sendiri cenderung untuk membeli produk dengan persepsi

\section{TELAAH LITERATUR}

Berdasarkan tujuan penelitian yang tertulis diatas, penelitian ini dapat dikatakan sejalan dengan Theory of Reasoned Action (TRA) yang membahas keterkaitan antara minat, sikap, dan perilaku seseorang (Tarkiainen \& Sundqvist, 2005). Theory of Reasoned Action membahas tentang minat dari perubahan tingkah laku seseorang yang terjadi akibat adanya dorongan dari norma subjektif (subjective norm) dan sikap (attitude). Perubahan tingkah laku individu sangat didorong oleh minat individu itu sendiri (Shaharudin, Pani, nilai yang tinggi (Dodds \& Monroe, 1985). Namun, untuk memiliki persepsi nilai yang tinggi, konsumen perlu untuk mempunyai pengetahuan yang cukup tentang produk yang akan dibeli sehingga produk bisa dianggap bernilai, dimana dalam konteks ini adalah makanan organik. Karena semakin banyak informasi yang diberikan kepada konsumen, membuat konsumen menganggap makanan organik sebagai sesuatu yang memiliki nilai dan layak untuk dibeli (Shaharudin, Pani, Mansor, \& Elias, 2010).

Mansor, \& Elias, 2010). Umumnya teori ini digunakan untuk mempelajari perilaku manusia. Perilaku seseorang ditentukan dari niat orang itu untuk mewujudkan perilaku yang diinginkan (Fishbein \& Ajzen, 1975). Tingkat kesadaran kesehatan adalah suatu kepedulian dan perhatian untuk menjadi lebih baik dan termotivasi dalam memperbaiki, mempertahankan, menjaga kesehatan dan kualitas hidup dengan menerapkan pola hidup sehat (Michaelidou \& Hassan, 2008). Kesadaran kesehatan adalah derajat individu peduli terhadap 
kesehatannya (Dutta-Bergman, 2004). Keamanan pangan terdefinisi sebagai terbebasnya makanan dari zat-zat atau bahan yang dapat membahayakan tubuh tanpa membedakan apakah zat itu secara alami terdapat dalam bahan makanan yang digunakan atau tercampur secara sengaja atau tidak sengaja ke dalam bahan makanan atau makanan jadi (Sucipto, 2015). Keamanan pangan sendiri semakin mendapat perhatian di negara berkembang, kesadaran konsumen akan informasi keamanan pangan dan analisis permintaan makanan juga terkait erat (Obayelu, Agboyinu, \& Awotide, 2014). Mereka mulai menyadari bahwa terdapat beberapa kekurangan keamanan dalam makanan konvensional (Shaharudin, Pani, Mansor, \& Elias, 2010). Perhatian terhadap keamanan pangan menjadi aspek yang penting dalam kegiatan sehari-hari (Syah, Utama, \& Mahrus, 2005). Variabel ini berfokus pada resiko apa saja yang mungkin akan diterima konsumen bila mengkonsumsi suatu produk. Hal ini bisa dilihat dari konsumen yang mulai memperhatikan faktor kebersihan maupun kandungan yang ada dalam makanan mereka. Sehingga, karena konsumen menganggap perhatian terhadap keamanan pangan sebagai faktor yang penting dalam pilihan makanan, mereka akan termotivasi untuk memilih makanan organik yang kemudian dapat meningkatkan minat beli terhadap makanan organik. Persepsi nilai adalah perbedaan antara evaluasi yang dilakukan konsumen atas keseluruhan manfaat dan biaya dari penawaran dan alternatif yang diterima (Kotler, Keller, Armstrong, Armstrong, \& Keller, 2016). Selain itu, definisi persepsi nilai adalah keseluruhan penilaian konsumen atas kegunaan suatu produk berdasarkan apa yang diterima dan diberikan produk itu (Zeithaml, 1988). Konsumen mau mengkonsumsi makanan organik karena persepsi mereka bahwa makanan organik memiliki banyak nutrisi dibanding makanan konvensional (Magnusson, Arvola, Hursti, Åberg, \& Sjödén, 2001). Minat beli didefinisikan sebagai konsumen yang cenderung membeli suatu merek dan mengambil tindakan yang berkaitan dengan pembelian, lalu diukur dengan kemungkinan konsumen tersebut mau mewujudkannya atau tidak (Assael, 1998). Yang dapat disingkat menjadi kemungkinan konsumen untuk membeli suatu produk (Lien, Wen, Huang, \& Wu, 2015). Selain itu, dapat berarti tindakan pengambilan keputusan yang dilakukan konsumen yang mempelajari beberapa alasan untuk membeli merek tertentu (Shah, et al., 2012).

Minat beli merupakan jenis pengambilan keputusan yang dilakukan konsumen 
dalam mempelajari beberapa alasan untuk membeli merek tertentu. Dalam konteks ini, untuk memunculkan minat beli terhadap makanan organik, ada beberapa faktor yang dapat mempengaruhinnya, antara lain adalah tingkat kesadaran kesehatan, perhatian terhadap keamanan pangan, dan persepsi nilai konsumen terhadap makanan organik. Tingkat kesadaran kesehatan adalah kondisi dimana orang memiliki kecenderungan untuk menaruh perhatian pada kesehatannya (Iversen \& Kraft, 2006). Dengan tingginya kesadaran kesehatan maka akan mempengaruhi minat beli konsumen terhadap makanan organik.

Kaitan antara Tingkat Kesadaran Kesehatan dan Minat Beli

Dalam beberapa tahun terakhir, pengaruh kesadaran kesehatan berfokus pada pola makan yang sehat (Wong \& Aini, 2017). Pola makan sehat bisa ditunjukkan dengan mengkonsumsi makanan organik. Pembeli produk organik sadar bahwa asupan makanan mempengaruhi kesehatan, sehingga mereka menghargai kesehatan dan makanan alami serta bersedia mengganti makanan mereka untuk meningkatkan kesehatan (Schifferstein \& Ophuis, 1998). Selain itu, masalah peningkatan perawatan kesehatan melalui nutrisi yang tepat merupakan faktor kunci yang mempengaruhi pilihan konsumsi yang berdampak pada minat beli makanan organik (Fotopoulos \& Krystallis, 2002). Hal ini didukung dengan penelitian yang mengatakan kesehatan adalah faktor utama yang mempengaruhi frekuensi pembelian (Magnusson, Arvola, Koivisto Hursti, Aberg, \& Sjoden, 2003).

Kaitan antara Perhatian terhadap Keamanan Pangan dan Minat Beli

Keprihatinan konsumen terhadap resiko kesehatan yang ditimbulkan oleh konsumsi pangan semakin meningkat (Lobb, Mazzocchi, \& Traill, 2007). Konsumen meragukan keamanan pangan yang beredar (Schifferstein \& Ophuis, 1998). Oleh karena itu mendorong konsumen untuk beralih ke makanan organik yang memiliki nutrisi lebih banyak (Magnusson, Arvola, Hursti, Åberg, \& Sjödén, 2001). Konsumen mempertimbangkan makanan organik karena makanan organik diproses tanpa menggunakan pestisida dan materi terkait pertanian lainnya yang dapat membahayakan kesehatan tubuh (Canavari \& Olson, 2007). Tidak sedikit konsumen yang rela bayar untuk mendapatkan nilai yang melekat pada peningkatan keamanan pangan sehingga resiko keracunan pangan berkurang (Henson, 1996). Hal ini didukung dengan 
hasil studi tentang keamanan pangan yang menjadi motif pembelian makanan organik (Schifferstein \& Ophuis, 1998).

Kaitan antara Persepsi Nilai dan Minat Beli

Konsumen cenderung akan membeli produk dengan persepsi nilai yang tinggi. Minat beli akan meningkat saat konsumen mendapat manfaat yang lebih banyak dari produk atas biaya yang sudah dikeluarkan (Dickson \& Sawyer, 1990).Nilai premium sangat bergantung pada makanan itu sendiri, seperti metode budidaya yang berbeda, cara penanganan yang menjamin minimasi resiko (Gil, Gracia, \& Sanchez, 2000). Konsumen memiliki persepsi bahwa makanan organik bernilai dan itulah alasan mereka mau membayar lebih. Ini didukung dengan penelitian yang mengatakan persepsi nilai memiliki dampak besar pada minat beli makanan organik (Shaharudin, Pani, Mansor, \& Elias, 2010).

\section{Penelitian yang Relevan}

Penelitian yang dilakukan (Shaharudin, Pani, Mansor, \& Elias, 2010) bertujuan untuk memahami bagaimana tingkat kesadaran kesehatan, perhatian terhadap keamanan pangan, persepsi nilai, dan faktor religious bisa mempengaruhi minat beli konsumen. Metode yang digunakan adalah deskriptif dengan penelitian kuantitatif. Sumber informasi dikumpulkan melalui kuesioner sebanyak 150 responden di Kedah, Malaysia. Hasil penelitian ini adalah tingkat kesadaran kesehatan dan persepsi nilai berpengaruh, sedangkan perhatian terhadap keamanan pangan dan faktor religious kurang berpengaruh terhadap minat beli konsumen. Penelitian oleh (Asif, Xuhui, Nasiri, \& Ayyub, 2018) bertujuan mengetahui pengaruh sikap, perceived behaviour control, norma subjektif, kesadaran lingkungan, dan tingkat kesadaran kesehatan yang dimoderasi oleh kesadaran konsumen terhadap minat beli. Data diperoleh dari kuesioner terstruktur yang ditanggapi 271 responden dari Pakistan, 245 responden dari Turki, dan 220 responden dari Iran dengan model persamaan structural. Hasil penelitian ini beragam di tiap negara tetapi sikap dan kesadaran kesehatan menjadi prediktor yang lebih baik untuk minat beli terhadap makanan organik. Kesadaran konsumen memoderasi secara positif minat pembelian makanan organik. Penelitian oleh (Hwang, 2016 bertujuan untuk mengetahui pengaruh dari presentasi diri, perhatian terhadap keamanan pangan, masalah lingkungan, dan identitas konsumen yang etis yang dimoderasi keinginan sosial membeli makanan organik terhadap minat beli 
konsumen. Data dikumpulkan dari sampel konsumen yang lebih tua melalui daftar email dari 600 karyawan di Universitas Midwestern, Amerika Serikat. Hasil penelitian menunjukkan presentasi diri dan perhatian terhadap keamanan pangan berpengaruh terhadap minat beli konsumen yang lebih tua, untuk masalah lingkungan dan identitas diri yang etis tidak meningkatkan minat beli konsumen.

Kerangka Pemikiran dalam penelitian ini seperti yang digambarkan dibawah ini:

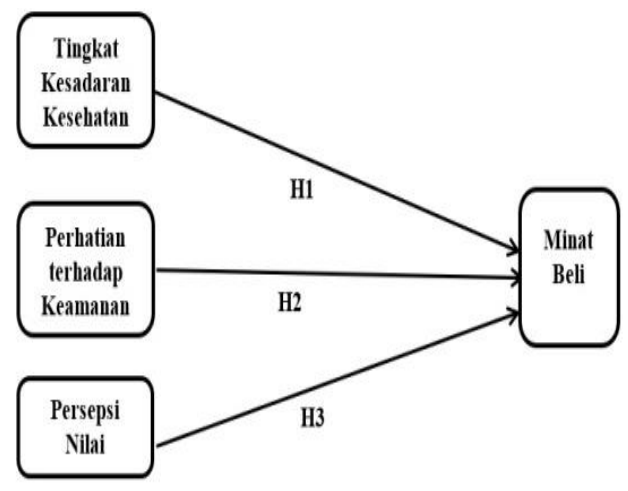

Gambar 1. Model Penelitian

Maka, hipotesis dalam penelitian ini dapat dirumuskan sebagai berikut:

H10 : Tidak terdapat pengaruh tingkat kesadaran kesehatan terhadap minat beli makanan organik di Jakarta

H1a: Terdapat pengaruh tingkat kesadaran kesehatan terhadap minat beli makanan organik di Jakarta

H20 : Tidak terdapat pengaruh perhatian terhadap keamanan pangan terhadap minat beli makanan organik di Jakarta

\section{METODOLOGI PENELITIAN}

Desain penelitian menggunakan jenis descriptive yang bertujuan untuk
H2a: Terdapat pengaruh perhatian terhadap keamanan pangan terhadap minat beli makanan organik di Jakarta H30: Tidak terdapat pengaruh persepsi nilai terhadap minat beli makanan organik di Jakarta

H3a: Terdapat pengaruh persepsi nilai terhadap minat beli makanan organik di Jakarta

mendeskripsikan karakteristik atau gambaran suatu aktivitas, situasi, atau seseorang (Sekaran \& Bougie, 2016). Penelitian ini memakai metode cross 
sectional dan menggunakan data primer dengan pendekatan kuantitatif. Populasi dalam penelitian ini adalah orang yang pernah membeli atau mengkonsumsi produk organik. Penelitian ini memakai non-probability sampling, dimana tidak semua anggota populasi memiliki kesempatan yang sama untuk dipilih menjadi sampel. Teknik pemilihan sampel yang digunakan adalah convenience sampling yang pengambilan sampelnya diambil berdasarkan unsur kemudahan dan tidak memakan bayak waktu dalam proses penelitiannya. Sampel diambil dari anggota klub

\section{HASIL DAN PEMBAHASAN}

Dalam PLS, terdapat dua jenis hasil uji validitas yakni validitas diskriminan dan validitas konvergen. Apabila nilai AVE (Average Variance Extracted) diatas 0,5 dan nilai loading factor dari setiap indikatornya diatas 0,7 maka validitas konvergen akan dianggap valid (Hair, Ringle, \& Sarstedt, 2011). Sedangkan validitas diskriminan melakukan analisis fornell-larcker yang digunakan untuk menganalisis tentang model pengukuran suatu nilai yang mana nilai dari setiap variabel AVE harus lebih besar dari nilai korelasi kuadrat tertinggi antar-variabel penelitian. Selain itu, juga dapat diukur melalui hasil nilai cross loadings dimana nilai indikator dari setiap variabel crossloading harus lebih besar dari cross kebugaran Gold's Gym di cabang Mal Ciputra. Alasan pengambilan sampel tersebut didasari bahwa orang yang sadar akan pentingnya kebugaran tentunya mengetahui pentingnya mengkonsumsi makanan organik. Data disebar secara online menggunakan kuesioner dengan Skala Likert dari 1 = sangat tidak setuju sampai 5 = sangat setuju dan telah ditanggapi sebanyak 40 responden konsumen anggota klub kebugaran Gold's Gym cabang Mal Ciputra Jakarta yang pernah membeli atau mengkonsumsi produk organik.

loadings dari indikator variabel lainnya (Garson, 2016). Di penelitian ini, hasil loading factor dari setiap variabel memiliki nilai lebih dari 0,7 dan hasil Average Variance Extracted bernilai diatas 0,5 sehingga memenuhi ketentuan uji validitas konvergen. Untuk hasil uji cross loadings dan fornell-larcker menunjukkan nilai yang dimiliki setiap variabel lebih besar dibanding variabel lainnya sehingga dapat dinyatakan setiap variabel sudah memenuhi kriteria uji validitas diskriminan. Ada dua metode uji reliabilitas yaitu cronbach's alpha dan composite reliability. Jika cronbach's alpha mengukur batas bawah nilai reliabilitas suatu konstruk, maka composite reliability mengukur nilai sesungguhnya reliabilitas suatu konstruk 
(Abdillah \& Hartono, 2015). Supaya indikator suatu variabel dapat diterima, nilai cronbach's alpha harus lebih besar dari 0,6 (Hussein, 2015). Sedangkan untuk nilai composite reliability dapat diterima bila memiliki nilai lebih besar dari 0,7 meskipun di angka 0,6 masih bisa diterima. Di penelitian ini, nilai Cronbach's Alpha dan Composite Reliability di setiap variabel berada diatas 0,6 untuk Cronbach's Alpha dan diatas 0,7 untuk Composite Reliability sehingga item di setiap variabel yang ada dapat dihandalkan karena dianggap telah reliabel. Uji $\mathrm{R}_{2}$ dilakukan untuk mengetahui besarnya kontribusi antara variabel independen terhadap variabel dependen. Hasil $R$-square akan mempunyai kontribusi yang kuat jika bernilai sebesar 0,67 , mempunyai kontribusi yang sedang jika bernilai sebesar 0,33, dan mempunyai kontribusi yang lemah jika bernilai sebesar 0,19 (Chin, 1998). Hasil uji nilai $\mathrm{R}_{2}$ adalah sebesar 0,714 . Artinya tingkat kesadaran kesehatan, perhatian terhadap keamanan pangan, dan persepsi nilai memiliki kontribusi yang kuat terhadap minat beli yaitu sebesar 71,4\%, sisanya sebesar $28,6 \%$ dapat dijelaskan oleh variabelvariabel lain yang tidak diteliti dalam penelitian ini. $\mathrm{Q}_{2}$ didapatkan dari proses blindfolding di SmartPLS 3.0 yang bertujuan untuk mengetahui hubungan konstruk pada variabel-variabel yang diteliti dalam mengukur model penelitian yang sudah terbentuk sebelumnya. Hasil uji $\mathrm{Q}_{2}$ adalah sebesar 0,450 untuk minat beli. Suatu variabel mampu memprediksi model dengan baik jika nilai Q2 bernilai lebih dari 0 (nol) (Hair, Ringle, \& Sarstedt, 2011). Nilai $\mathrm{Q}_{2}$ sebesar 0,450 lebih besar dari nol yang berarti semua variabel dalam penelitian ini dapat memprediksi model dengan baik. Uji Goodness of Fit (GoF) dihitung secara manual yang membutuhkan nilai AVE dan $R_{2}$ dalam penelitian ini. Berikut adalah perhitungan nilai Goodness of Fit (GoF) :

$$
\begin{gathered}
\overrightarrow{A V E}=(0.684+0.836+0.725+0.607) / 4=0.713 \\
\mathrm{R}^{2}=0,714 \\
\text { Maka, } \\
\mathrm{GoF}=\sqrt{\overrightarrow{A V E} \times \vec{R}^{2}} \\
\mathrm{GoF}=\sqrt{0,713 \times 0,714}
\end{gathered}
$$$$
\mathrm{GoF}=0.713
$$ 
Dari hasil perhitungan di atas, maka dikatakan bahwa model yang digunakan di penelitian ini memiliki kecocokan dan nilai Goodness of Fit tergolong besar yaitu 0,5720. Dimana GoF akan tergolong kecil bila bernilai 0,1, akan tergolong sedang bila bernilai 0,25 , dan akan tergolong besar bila bernilai 0,38 (Wetzels, Odekerken-Schröder, \& Van Oppen, 2009). Pengujian hipotesis dilakukan untuk mengetahui apakah suatu hipotesis dapat ditolak atau tidak ditolak. Hal ini dilakukan dengan cara membandingkan nilai $P$-values dan nilai $T$-statistics menggunakan hasil pengujian bootstrapping. Jika nilai $P$-values kurang dari 0,05 dan nilai T-statistics lebih besar dari 1,96 maka hipotesis dapat diterima dan memiliki pengaruh yang signifikan terhadap variabel dependen. Berdasarkan hasil pengujian variabel Tingkat Kesadaran Kesehatan terhadap Minat Beli, dapat dikatakan bahwa H10 ditolak karena variabel Tingkat Kesadaran Kesehatan memiliki nilai T-statistics sebesar 3,256 yang berarti lebih besar dari 1,96 dan nilai $P$-values sebesar 0,001 yang berarti lebih kecil dari 0,05.Maka dapat dikatakan bahwa variabel Tingkat Kesadaran Kesehatan memiliki pengaruh yang signifikan terhadap variabel Minat
Beli. Berdasarkan hasil pengujian variabel Perhatian terhadap Keamanan Pangan terhadap Minat Beli, dapat dikatakan bahwa H20 tidak ditolak karena Perhatian terhadap Keamanan Pangan memiliki nilai $T$-statistics sebesar 1,388 yang berarti kurang dari 1,96 dan nilai $P$-values sebesar 0,166 yang berarti lebih besar dari 0,05. Maka dapat dikatakan bahwa Perhatian terhadap Keamanan Pangan tidak memiliki pengaruh yang signifikan terhadap Minat Beli. Berdasarkan hasil pengujian variabel Persepsi Nilai terhadap Minat Beli, dapat dikatakan bahwa H30 ditolak karena Persepsi Nilai memiliki nilai Tstatistics sebesar 2,384 yang berarti lebih besar dari 1,96 dan nilai P-values sebesar 0,018 yang berarti lebih kecil dari 0,05. Maka dapat dikatakan bahwa Persepsi Nilai memiliki pengaruh yang signifikan terhadap Minat Beli. Berdasarkan penjelasan tentang uji hipotesis di atas, dapat dilihat bahwa Tingkat Kesadaran Kesehatan dan Persepsi Nilai memiliki pengaruh yang signifikan terhadap Minat Beli makanan organik di Jakarta. Sedangkan Perhatian terhadap Keamanan Pangan tidak memiliki pengaruh yang signifikan terhadap Minat Beli makanan organik di Jakarta. 


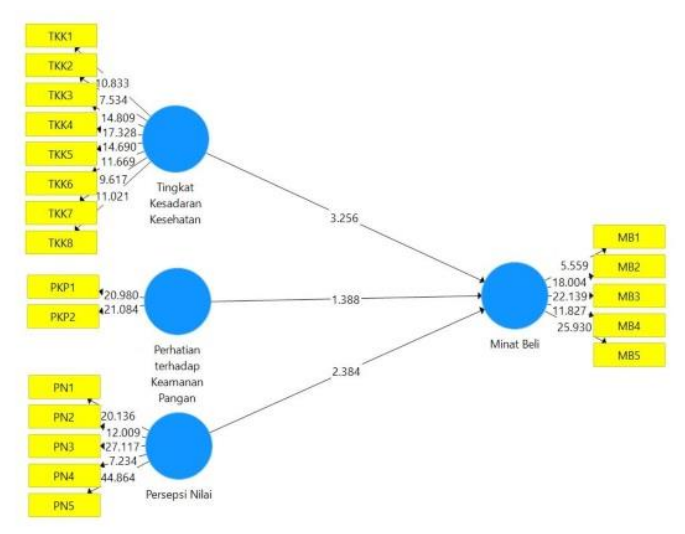

Gambar 2. Hasil Bootstraping

Hasil dari pengujian hipotesis yang pertama $\left(\mathrm{H}_{1}\right)$ menunjukkan bahwa tingkat kesadaran kesehatan memiliki pengaruh terhadap minat beli makanan organik yang berarti H10 ditolak. Hal ini sejalan dengan penelitian yang dilakukan (Shaharudin, Pani, Mansor, \& Elias, 2010) yang mengatakan bahwa kesadaran kesehatan berpengaruh secara signifikan terhadap minat beli. Melalui tingkat kesadaran kesehatan, konsumen akan lebih bijaksana dalam memilih makanan yang tepat yang kemudian akan membawa mereka untuk membeli makanan organik. Maka, untuk dapat meningkatkan minat beli terhadap makanan organik, konsumen perlu fokus pada makan makanan yang sehat seperti makanan organik. Penyedia produk organik bisa memanfaatkan kesempatan ini untuk mempromosikan produk mereka melalui berbagai platform seperti sosial media supaya produk bisa lebih dikenal masyarakat. Apalagi dengan munculnya fenomena Covid-19 seharusnya membuat konsumen semakin memperhatikan kesehatan tubuh mereka dan melakukan refleksi diri apakah mereka sudah melakukan yang terbaik dalam upaya menjaga kesehatan supaya bisa terhindar dari paparan virus yang ada. Untuk itu konsumen juga harus mau berkorban waktu untuk berolahraga maupun berkorban mengeluarkan biaya lebih untuk membeli produk organik. Agar pengorbanan yang dilakukan tidak sia-sia konsumen juga perlu untuk selalu waspada dan sangat sadar terhadap kesehatannya. Penting bagi konsumen untuk memahami bagaimana cara memakan makanan yang sehat. Penyedia produk organik bisa membantu konsumen dengan memberikan informasi tambahan di belakang kemasan tentang bagaimana cara mengolah produk organik tersebut. Dengan melakukan tindakan tersebut, diharapkan konsumen muncul rasa tanggung jawab terhadap kesehatannya dan mulai berkomitmen menerapkan pola hidup sehat. Hal ini karena konsumen 
sadar bahwa kesehatan diperoleh dari tindakan nyata atas pertanggungjawaban diri mereka. Penyedia produk organik bisa membantu konsumen untuk mewujudkan tindakan tersebut dengan cara mendorong mereka untuk rutin mengkonsumsi makanan organik. Hasil dari pengujian hipotesis yang kedua $\left(\mathrm{H}_{2}\right)$ menunjukkan bahwa perhatian terhadap keamanan pangan memiliki pengaruh terhadap minat beli makanan organik yang berarti H20 tidak ditolak. Hal ini sejalan dengan penelitian sebelumnya yang dilakukan (Shaharudin, Pani, Mansor, \& Elias, 2010) yang mengatakan bahwa perhatian terhadap keamanan pangan adalah faktor yang dianggap kurang berpengaruh dalam meningkatkan minat beli makanan organik karena konsumen menganggap bisa menyerahkan tanggung jawab terkait faktor ini kepada pemerintah masingmasing atau otoritas lokal untuk meninjau masalah keamanan pangan yang beredar. Bagi beberapa konsumen, selama penjual memiliki izin untuk beroperasi maka itu akan cukup meyakinkan konsumen untuk membeli produk makanan organik di pasaran. Maka untuk dapat meningkatkan minat beli konsumen terhadap makanan organik, penyedia produk organik perlu mengingatkan konsumen terkait faktor keamanan pangan yang beredar. Konsumen harus menyadari bahwa makanan yang dijual di pasaran memiliki tingkat keamanan dan kebersihan yang rendah. Tidak sedikit peternak yang melakukan suntik hormon ataupun suntik antibiotik supaya hewan bisa berkembang dengan cepat, terlihat lebih subur, dan mencegah terkena penyakit walaupun hewan tinggal di tempat yang kotor dan kumuh. Sedangkan untuk buah dan sayuran, tidak sedikit petani yang menanamnya menggunakan pestisida yang berbahaya. Dengan adanya kekhawatiran ini, penyedia produk organik bisa meyakinkan konsumen bahwa produk yang mereka hasilkan tidak mengandung bahan yang berbahaya sehingga resiko konsumen untuk terjangkit penyakit bawaan hewan seperti flu burung atau flu babi berkurang dan keamanan daging juga lebih terjaga. Hasil dari pengujian hipotesis yang ketiga $\left(\mathrm{H}_{3}\right)$ menunjukkan bahwa persepsi nilai memiliki pengaruh terhadap minat beli, yang berarti H30 ditolak. Hal ini sesuai dengan penelitian (Shaharudin, Pani, Mansor, \& Elias, 2010) yang mengatakan faktor persepsi nilai adalah faktor yang dapat mempengaruhi minat beli konsumen terhadap makanan organik. Harga bukan menjadi masalah utama apabila makanan organik mampu memberikan nilai gizi yang lebih tinggi dibandingkan makanan konvensional yang beredar di pasaran. Semua ini bisa 
terjadi jika manfaat produk organik dapat dikomunikasikan dengan baik kepada konsumen. Penting untuk meningkatkan kesadaran nilai produk organik dan mengembangkan tingkat kesadaran kesehatan di kalangan konsumen. Hal ini bisa dilakukan dengan membawa program kesadaran produk yang efektif dalam pameran dagang, tour keliling, dan iklan secara teratur. Maka untuk dapat membangun persepsi nilai yang bagus, konsumen perlu memahami secara jelas apa saja keuntungan yang dapat diperoleh jika mereka mengkonsumsi makanan organik. Penyedia produk organik bisa memberikan informasi tentang manfaat mengkonsumsi makanan organik atau membagikan artikel tentang dampak dari menjalani pola hidup yang tidak sehat yang dibagikan melalui platform yang dimiliki. Karena semakin banyak informasi yang didapatkan akan membuat konsumen semakin memandang makanan organik sebagai sesuatu yang memiliki nilai dan layak untuk dibeli. Penyedia produk organik juga bisa mengadakan

\section{SIMPULAN}

Berdasarkan hasil pembahasan yang diperoleh, peneliti akan memberikan saran yang sekiranya dapat bermanfaat untuk penelitian selanjutnya. Berikut saran yang diberikan:

1. Peneliti menyarankan supaya pada penelitian selanjutnya untuk topik webinar dengan menggandeng seorang dokter atau ahli gizi serta influencer ternama supaya konsumen tertarik mengikuti acara dan lebih percaya terhadap produk tersebut. Jika konsumen memiliki informasi yang cukup, mereka akan menyadari bahwa makanan organik memiliki banyak keunggulan antara lain nilai gizi dan tingkat kesegaran yang lebih tinggi dibanding makanan konvensional. Ini dikarenakan produk organik diolah secara natural tanpa melibatkan bahan kimia berbahaya sehingga lebih menyehatkan tubuh konsumen. Penyedia produk organik bisa menekankan keunggulan tersebut ada dalam produk yang dijual sehingga tercipta persepsi nilai yang tinggi di mata konsumen. Dengan adanya keunggulan tersebut, konsumen akan menyadari bahwa makanan organik memiliki kualitas yang lebih tinggi dibanding makanan konvensional karena tidak hanya manfaatnya saja yang dapat diperoleh namun juga cita rasa yang diberikan juga lebih lezat.

yang sama, penelitian mengalami perkembangan pada variabel lainnya seperti faktor religious, kepedulian lingkungan, tingkat kesegaran. Selain itu juga dapat dilakukan penambahan jumlah sampel, perluasan wilayah, dan penambahan karakteristik 
$\begin{array}{lll}\text { responden supaya bisa } & \\ \text { memberikan manfaat bagi } & \\ \text { masyarakat yang lebih luas. }\end{array}$

2. Peneliti menyarankan penyedia produk organik supaya terus menjaga kualitas dari produk yang dihasilkan dan

3. selalu menjaga keamanan pangan seperti tidak menggunakan pestisida atau bahan kimia lainnya sehingga bisa memberikan nutrisi bagi konsumen yang membelinya. Karena sebagian besar konsumen berharap dengan membeli produk organik bisa memperoleh nilai gizi dan tingkat kesegaran yang lebih tinggi dibanding makanan biasa.

4. Peneliti juga menyarankan penyedia produk organik melakukan promosi iklan maupun mengadakan webinar dengan menggandeng dokter atau ahli gizi dengan membahas manfaat yang dapat diperoleh dari produk organik supaya bisa meningkatkan kesadaran terhadap kesehatan dan membangun persepsi nilai yang tinggi di mata konsumen.

\section{DAFTAR PUSTAKA}

Abdillah, W., \& Hartono, J. (2015). Partial Least Square (PLS): alternatif structural equation modeling (SEM) dalam penelitian bisnis. . Yogyakarta: Penerbit Andi.

Annunziata, A., \& Pascale, P. (2009). Consumers' behaviours and attitudes toward healthy food products: The case of Organic and Functional foods . EAAE Seminar, No. 698-2016-47803.

Asif, M., Xuhui, W., Nasiri, A., \& Ayyub, S. (2018). Determinant factors influencing organic food purchase intention and the moderating role of awareness: A comparative analysis. Food Quality and Preference, 63, 144-150.

Assael, H. (1998). Consumer Behaviour And Marketing Action 6th edition 6th edition. New York, South Western.

Beharrel, B., \& MacFie, J. (1991). Consumer attitudes to organic

foods . British Food Journal, Vol. 93, 25-30.

Canavari, M., \& Olson, K. D. (2007). Organic Food. Berlin, Germany: Springer.

Chin, W. (1998). The partial least squares approach to structural equation modeling. London: Lawrence Erlbaum Associates.

Dickson, R. P., \& Sawyer, A. G. (1990). The Price Knowledge and Search of Supermarket Shoppers. Journal of Marketing, 54 (3), 42-53.

Dodds, W. B., \& Monroe, K. B. (1985). The effect of brand and price information on subjective product evaluations . ACR North American Advances, 85-90.

Dutta-Bergman, M. J. (2004). Primary sources of health information: Comparisons in the domain of health attitudes, health cognitions, and health behaviors. . Health communication, 16(3), 273-288. 
Fishbein, M., \& Ajzen, I. (1975). Belief, Attitude, Intention and Behaviour. An Introduction to Theory and Research, Addison-Wesley, Reading, MA.

Fotopoulos, C., \& Krystallis, A. (2002). Organic product avoidance. Reasons for rejection and potential buyers' identification in a countrywide survey. British Food Journal, 104 (3-5), 233-260.

Głąbska, D., Skolmowska, D., \& Guzek, D. (2020). Population-Based Study of the Changes in the Food Choice Determinants of Secondary School Students: Polish Adolescents' COVID-19 Experience (PLACE19) Study. Nutrients, 12(9), 2640.

Garson, G. D. (2016). PARTIAL LEAST SQUARES (PLS-SEM): Regression and Structural Equation Models. North Carolina: Statistical Publishing Associates.

Gil, J., Gracia, A., \& Sanchez, M. (2000). Market segmentation and willingness to pay for organic. International Food and Agribusiness Management Review, Vol.3, pp. 207-26.

Hair, J. F., Ringle, C. M., \& Sarstedt, M. (2011). PLS-SEM: Indeed a silver bullet. . Journal of Marketing theory and Practice, 19(2), 139152.

Henson, S. (1996). Consumer willingness to pay for reductions in the risk of food poisoning in the UK. Journal of Agricultural Economics, 47(1-4), 403-420.

Hussein, A. S. (2015). Penelitian bisnis dan manajemen menggunakan partial least squares (pls) dengan smartPLS 3.0. . Universitas Brawijaya.

Hwang, J. (2016). Organic food as selfpresentation: The role of psychological motivation in older consumers' purchase intention of organic food. Journal of Retailing and Consumer Services, 28, 281287.
Kotler, P., Keller, K. L., Armstrong, G., Armstrong, G., \& Keller, K. (2016). Marketing management. 15th Global Edition. England: Pearson Educationn Limited, 17.

Kriwy, P., \& Mecking, R. A. (2012). Health and environmental consciousness, costs of behaviour and the purchase of organic food. International Journal of Consumer Studies 36(1), 30-37.

Krystallis, A., Fotopoulos, C., \& Zotos, Y. (2006). Organic consumers' profile and their willingness to pay (WTP) for selected organic food products in Greece. ournal of international consumer marketing, 19(1), 81-106.

Lien, C., Wen, M., Huang, L., \& Wu, K. (2015). Online Hotel Booking: The Effects of Brand Image, Price, Trust and Value on Purchase Intentions. Asia Pacific Management Review, 20(4), 210218.

Lobb, A. E., Mazzocchi, M., \& Traill, W. B. (2007). Modelling risk perception and trust in food safety information within the theory of planned behaviour. Food quality and preference, 18(2), 384-395.

Magnusson, M. K., Arvola, A., Hursti, U. K., Åberg, L., \& Sjödén, P. O. (2001). Attitudes towards organic foods among Swedish consumers. British food journal.

Magnusson, M. K., Arvola, A., Koivisto Hursti, U.-K., Aberg, L., \& Sjoden, P.-O. (2003). Choice of organic foods is related to perceived consequences for human health and to environmentally friendly behavior. Appetite, Vol. 40 No. 2, pp. 109-17.

Michaelidou, N., \& Hassan, L. M. (2008). The role of health consciousness, food safety concern and ethical identity on attitudes and intentions towards organic food. . International journal of consumer studies 32(2), 163-170. 
Obayelu, O. A., Agboyinu, O. M., \& Awotide, B. A. (2014). Consumers' perception and willingness to pay for organic leafy vegetables in urban Oyo State, Nigeria. European Journal of Nutrition \& Food Safety, 127-136.

Qi, X., Yu, H., \& Ploeger, A. (2020). Exploring Influential Factors Including COVID-19 on Green Food Purchase Intentions and the Intention-Behaviour Gap: A Qualitative Study among Consumers in a Chinese Context. International Journal of Environmental Research and Public Health, 17(19), 7106.

Salleh, M. M., Ali, S. M., Harun, E. H., Jalil, M. A., \& Shaharudin, M. R. (2010). Consumer's perception and purchase intentions towards organic food products: Exploring attitude among academician. Canadian Social Science, 6(6), 119-129.

Schifferstein, H. N., \& Ophuis, P. A. (1998). Health-related determinants of organic food consumption in the Netherlands. Food Quality and Preference, 9 (3), 119-133.

Sekaran, U., \& Bougie, R. (2016). Research methods for business: A skill building approach.

Shah, S. S., Aziz, J., Jaffari, A. R., Waris, S., Ejaz, W., Fatima, M., \& Sherazi, S. K. (2012). The impact of brands on consumer purchase intentions. Asian Journal of Business Management, 4(2), 105-110.

Shaharudin, M. R., Pani, J. J., Mansor, S. W., \& Elias, S. J. (2010). Factors affecting purchase intention of organic food in Malaysia's Kedah state.

Cross-Cultural Communication, 6(2), 105-116.

Shaharudin, M. R., Pani, J. J., Mansor, S. W., \& Elias, S. J. (2010). Purchase intention of organic food; perceived value overview. Canadian Social
Science, 6(1), 70-79.

Shepherd, R., Magnusson, M., \& Sjödén, P. O. (2005). Determinants of consumer behavior related to organic foods. AMBIO: A Journal of the Human Environment, 34(4), 352-359.

Sucipto, C. D. (2015). Keamanan Pangan Untuk Kesehatan Manusia. Yogyakarta: Gosyen Publishing.

Suh, B. W., Eves, A., \& Lumbers, M. (2012). Consumers' Attitude and Understanding of Organic Food: The Case of South Korea. Journal of foodservice business research, 15(1), 49-63.

Tarkiainen, A., \& Sundqvist, S. (2005). Subjective norms, attitudes and intentions of Finnish consumers in buying organic food. British food journal., 808-822.

Waskito, D., Ananto, M., \& Reza, A. (2014). Persepsi Konsumen Terhadap Makanan Organik Di Yogyakarta. Pelita-Jurnal Penelitian Mahasiswa UNY, 36.

Wetzels, M., Odekerken-Schröder, G., \& Van Oppen, C. (2009). Using PLS path modeling for assessing hierarchical construct models: Guidelines and empirical illustration. . MIS quarterly, 177195.

Wong, S. S., \& Aini, M. S. (2017). Factors influencing purchase intention of organic meat among consumers in Klang Valley, Malaysia.International Food Research Journal, 24(2).

Zeithaml, V. A. (1988). Consumer perceptions of price, quality, and value: a means-end model and synthesis of evidence. Journal of marketing, 52(3), 2-22. 